\title{
Ventilation in low energy residences - A survey on code requirements, implementation barriers and operational challenges from seven European countries
}

\author{
Daria Zukowska ${ }^{\mathrm{a}}$, Gabriel Rojas ${ }^{\mathrm{b}}$, Esfand Burman ${ }^{\mathrm{c}}$, Gaelle Guyot ${ }^{\mathrm{d}, \mathrm{e}}$, Maria del \\ Carmen Bocanegra-Yanez ${ }^{\mathrm{f}}$, Jelle Laverge ${ }^{\mathrm{g}}$, Guangyu $\mathrm{Cao}^{\mathrm{h}}$ and Jakub Kolarik ${ }^{\mathrm{a}}$
}

\author{
aTechnical University of Denmark, Brovej 118, 2800 Kgs. Lyngby, Denmark \\ ${ }^{\mathrm{b}}$ Salzburg University of Applied Sciences, $5431 \mathrm{Kuchl}$, Austria \\ ${ }^{c}$ UCL Institute for Environmental Design and Engineering, 14 Upper Woburn Place, London \\ WC1H 0NN, United Kingdom \\ ${ }^{\mathrm{d}}$ Cerema, Project team BPE, 46, rue St Théobald, F-38080, L'Isle d'Abeau, France \\ 'Université Grenoble Alpes, Univ. Savoie Mont Blanc, CNRS, LOCIE, 73000 Chambéry, \\ France \\ fUniversity of Strathclyde, 16 Richmond Street, G11XQ Glasgow, United Kingdom \\ ${ }^{\mathrm{g}}$ Ghent University, Jozef Plateaustraat 22, 9000 Gent, Belgium \\ ${ }^{\mathrm{h}}$ Norwegian University of Science and Technology, Kolbjørn Hejes vei 1b, 7491 Trondheim, \\ Norway
}

Corresponding author: Daria Zukowska,dz@byg.dtu.dk

\begin{abstract}
This paper reports the results of an interview survey conducted among different stakeholders involved in design, installation and operation of residential ventilation in seven European countries. In total 44 interviews were performed. The results provide a valuable snapshot of current practices and insights into potential barriers and challenges regarding installation of mechanical ventilation in low-energy residences to maintain high indoor air quality (IAQ). The results show that mechanical ventilation with heat recovery is becoming a common choice in new low energy residences in Europe. However, there are countries that apply airing or other types of ventilation such as mechanical exhaust or natural ventilation due to tradition, national legislation, climatic conditions and/or cost reasons. Demand-controlled ventilation (DCV) is often allowed or even recommended in standards, but rarely implemented in practice, except for exhaust-only humidity-based DCV in France and Belgium. The main barriers against mechanical ventilation seem to be high capital cost, space requirements and duct routing. The respondents commonly reported problems resulting from poor construction, lack of commissioning and/or maintenance. The main needs identified in the survey were: more legislative pushes including more flexibility in legislation, a coordinated approach to energy efficiency and IAQ, and control mechanisms to ensure good implementation and operation.
\end{abstract}

\section{KEYWORDS}

Residential ventilation, mechanical ventilation with heat recovery, low-energy housing, indoor air quality 
Abbreviations:

$\mathrm{ACH}$ - air change rate

AHU - air handling unit

DCV - demand-controlled ventilation

EP - energy performance

EPBD - Energy Performance of Buildings Directive

IEQ - indoor environmental quality

HVAC - heating, ventilation and air-conditioning

IAQ - indoor air quality

$\mathrm{NV}$ - natural ventilation

MEV - mechanical exhaust ventilation

MFH - multi-family houses

MSV - mechanical supply ventilation

MV - mechanical ventilation

MVHR - mechanical ventilation with heat recovery

nZEBs - nearly-zero energy buildings

PH - Passive House

PHPP - Passive House Planning Package

RH - relative humidity

SFH - single-family houses

SPI - specific power input

UK - the United Kingdom

\section{INTRODUCTION}

To reduce building energy consumption and carbon emissions, building regulations and standards require more insulated and airtight buildings, which may lead to poor quality of the indoor environment in case of insufficient ventilation. Due to tightly insulated building envelopes, providing sufficient amount of fresh air becomes more important than ever in newly built or refurbished residential dwellings to ensure high indoor air quality (IAQ). In this case, airing (defined as a renewal of air by opening of windows) or natural ventilation (NV) (defined as ventilation designed solely on the effect of wind and the stack effect through dedicated openings, i.e. excluding infiltration) (EN 15665:2009; CEN/TR 14788:2006) are often unable to provide adequate ventilation for odour or contaminant removal. Mechanical ventilation (MV) is necessary to achieve minimum ventilation rates (Dimitroulopoulou, 2012) in many cases. Several studies show that low-energy buildings with mechanical ventilation can provide better IAQ than corresponding homes ventilated by airing or natural ventilation (Colcough et al., 2018; Mahdavi and Doppelbauer, 2010; Rojas et al., 2016; Sharpe et al., 2016; Wallner et al., 2015; Wang et al., 2018). However, various studies reported in situ ventilation performance to be rather low in new and existing dwellings, often not complying with the minimum rates required by the respective building regulations (Boerstra, 2012; Caillou et al., 2012; Jobert and Guyot, 2013; Guyot et al., 2017; McGill et al., 2014).

One of the key objectives of the collaborative research project entitled "Indoor Air Quality Design and Control in Low Energy Residential Buildings", performed under the framework of the International Energy Agency (IEA), IEA EBC Annex 68, has been to identify improvement opportunities for the design and operation of ventilation in residential buildings. To fulfil this objective, an investigation of the current situation regarding requirements and practices in the countries involved in the project was necessary. Without a strong alignment between requirements and practices, no progress towards high IAQ in residences can be achieved. First, 
a review of the ventilation requirements and available guidelines for practicioners dealing with ventilation in seven European countries, participating in IEA EBC Annex 68, was conducted. Subsequently, interviews with relevant expert groups in these countries were carried out. Findings from the interviews were used to map the transition between today's strict requirements (i.e. EU directives, national building codes, standards) and the actual situation in practice. Identification of key barriers, challenges and needs regarding design, commissioning, operation and maintenance of ventilation systems is a first step to ensure high IAQ in low energy domestic buildings.

\section{METHODOLOGY}

\subsection{Review of national requirements}

A review of the national building regulations and standards in Austria, Belgium, Denmark, Estonia, France, Norway and the United Kingdom (UK) was conducted. The review focused on ventilation requirements with special attention to key aspects, such as:

- recommended ventilation systems (if any)

- background and nominal ventilation rates

- supply and extract airflows from habitable rooms, bathroom, toilet and kitchen

- state-of-the-art system typology

- requirements for heat recovery efficiency and specific power input (SPI)

- requirements for demand-controlled ventilation (DCV)

\subsection{Review of guidelines for practitioners}

The Annex 68 participants who contributed to this study reviewed the available guidance for the practitioners dealing with ventilation on a national level by using spreadsheet-based evaluation forms. The review provided information about written guidelines, internet-based knowledge platforms and computational tools available to the practitioners in their country. The forms included fields describing the target group as well as the key objective of the particular guide, e.g. guidance with respect to building code requirements and building renovations. In addition, the structure and form of the guidance was reviewed (textbooks and other printed material, internet-based materials, videos and computational tools). It was also noted what building typology (single-family houses, apartment buildings) and a type of recommended ventilation systems (natural/airing, hybrid, and balanced mechanical ventilation) was the focus of the guide.

\subsection{Stakeholder survey}

Information about the current practices in design, operation and commissioning of residential ventilation systems was gathered using semi-structured interviews. Five different interview templates were prepared dependent on the target group of stakeholders to be interviewed: A. Ventilation designers/consultants, B. Facility management companies/ Building administration, C. Public authorities, D. Housing developers and E. Producers of ventilation systems. Each survey template consisted of two parts. The first part focused on the stakeholders' opinion regarding state-of-the-art ventilation systems installed in low-energy dwellings. The second part focused on barriers and problems during design, commissioning, operation and maintenance. Key changes in legislation, technical measures, financial incentives, market requirements and outreach programmes that stakeholders believed were needed to provide high IAQ in energy efficient homes were also noted. Each of the two parts included three to four main (open) questions as well as several more precisely defined sub-questions, which should help the interviewer to keep structure of the interview. Table 1 shows a selection of the questions chosen for analysis in the present paper. 
Table 1. Interview questions selected to be analysed.

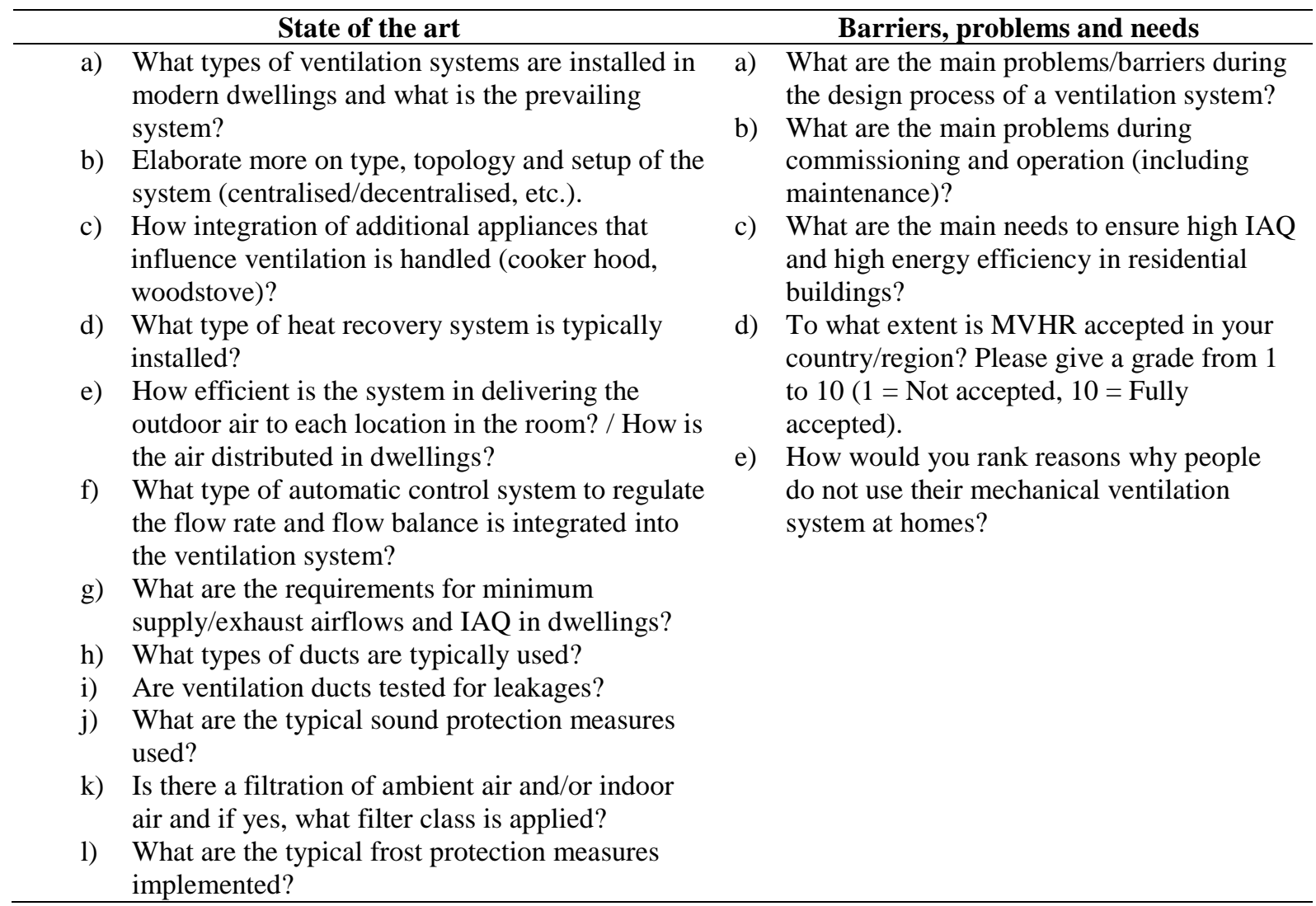

\section{RESULTS AND DISCUSSION}

\subsection{Review of national requirements}

To improve energy performance of buildings, the EU has established a legislative framework that includes the Energy Performance of Buildings Directive 2010/31/EU (EPBD) and the Energy Efficiency Directive 2012/27/EU. Both directives were amended in 2018 and 2019. The amended EPBD covers a broad range of policies and supportive measures that will help national EU governments improve energy performance of buildings, including promotion of smart technologies, for instance through requirements on the installation of building automation and control systems, and on devices regulating temperature at room level. EU countries will have to express their national energy performance requirements in ways that allow cross-national comparisons. Health and well-being of building users will be promoted, for instance through an increased consideration of air quality and ventilation.

Actual requirements regarding residential ventilation in the seven investigated countries are listed in Table 2. Dependent on the country, the regulations addressing ventilation issues either deal with energy performance (EP), or with IAQ, or are global performance regulations (both $\mathrm{EP}$ and IAQ). Moreover, they can represent international building performance regulations (EP and IAQ) or are based on specific national regulations. Generally, the regulations may not support any specific ventilation strategy but rather refer to global performance indicators to be reached, notably the target of low-energy buildings in the Energy Performance of Buildings Directive (EPBD) (Directive 2002/91/EC, Directive 2010/31/EU) context. For instance, for France, content of Table 2 results from the national EP regulation targeting low-energy buildings in line with the EPBD (Arrêté 26.10.2010, 2010)), and from the national sanitary regulation for residential buildings (Arrêté 24.03.82, 1983), which also refers to the calculation 
rules described in national technical guidelines for demand-controlled ventilation (CCFAT, 2015). Denmark and Norway have national building codes (BR18, 2019 and TEK17, 2017, respectively), which contain the requirements for construction of buildings, both private and commercial. The two regulations are based on functional requirements, but they also specify performance requirements. In case of ventilation for new residences, the minimum requirements regarding IAQ and energy efficiency are very detailed as shown in Table 2. Another approach can be seen in Estonia. Its building code does not set the requirements for residential ventilation, but engineers follow the voluntary guidelines presented in EVS-EN 16798-1:2019, which specifies indoor environmental input parameters for design and assessment of energy performance of buildings addressing indoor air quality, thermal environment, lighting and acoustics. The national annex EVS-EN 16798-1:2019/NA:2019 gives special requirements in order to apply the European Standard's Annex A in Estonia. However, a new IEQ regulation is expected to enter into force in 2021. It will make the ventilation requirements binding in Estonia and go hand-in-hand with the energy performance regulation. Austria's national implementation of the EPBD, i.e. OIB-Richtlinie 6 (2019), does not address ventilation or IAQ requirements. Those are vaguely formulated in OIB-Richtlinie 3 (2019), while ÖNORM H 6038 (2014) addresses only requirements to mechanical ventilation. The building regulations in the United Kingdom (UK) are devolved to local governments, although generally similar principles underpin the national building codes. For example, in England Approved Documents Part L (2013) and Part F (2010) cover the requirements for energy performance and ventilation of buildings respectively and support the implementation of the EPBD. The Belgian ventilation requirements for residential buildings are included in a national standard NBN D 50-001 (1991) that has been included in the national implementation of the EPBD with some minor amendments. They have therefore become minimum requirements for the sizing of ventilation systems in new construction and deep renovation projects.

Mechanical ventilation is not expressly required in any of the countries. In most countries, the recommendations do not prioritize mechanical ventilation (MV), natural ventilation (NV) or airing. However, in the seven countries the requirements regarding minimum ventilation rates and energy are the same independent what ventilation principle has been chosen. For example, the Belgian building regulation classifies residential ventilation systems into four main categories A-D, i.e. natural ventilation, supply ventilation, extract ventilation and balance ventilation, respectively. The two first systems are not recommended for buildings higher than $13 \mathrm{~m}$ above the ground level. Requirements related to minimum heat recovery efficiency in new mechanical systems apply only to Denmark and Norway. However, there is a recommendation for this in regulations in the UK. The Estonian regulations allow to make MV without heat recovery if the energy requirements are fulfilled. However, in practice, it is almost impossible to meet the energy requirements as now only nearly-zero energy buildings (nZEBs) can be designed and built in Estonia.

All countries have requirements for nominal ventilation rates (see Table 2). The requirements vary among the countries and are for some given as air change rate $(\mathrm{ACH})$, while for others airflows depend on the number of occupants, floor area, number of habitable rooms (i.e. living rooms, bedrooms, offices, etc.) or number of bedrooms only. The regulations clearly state that it is not allowed to switch off mechanical ventilation system completely in case of Belgium and France. The Danish building regulations allow for that in summer period by stating that outside heating season, mechanical air supply can be replaced by airflows through windows, outdoor air valves, etc. but the minimum airflow rate has to be ensured. Reminding four countries do not have regulations addressing this issue. However, it is allowed to reduce the airflow below 
the nominal airflow in some countries, namely in Norway, Austria and Estonia during nonoccupancy and in case of a DCV system in France, Belgium, Estonia and the UK.

The national building codes set requirements for minimum exhaust rates from wet rooms in all investigated countries. For example:

- In France, the minimum extract rates depend on the number of habitable rooms: in a 3room dwelling, the required extraction rate is $45 \mathrm{~m}^{3} / \mathrm{h}$ (i.e. $12.5 \mathrm{l} / \mathrm{s}$ ) for a kitchen and 75 $\mathrm{m}^{3} / \mathrm{h}$ (i.e. $20.8 \mathrm{l} / \mathrm{s}$ ) for the whole dwelling, but it can be reduced to $15 \mathrm{~m}^{3} / \mathrm{h}$ (i.e. $4.2 \mathrm{l} / \mathrm{s}$ ) with DCV.

- According to the Danish building regulations, extraction of at least $20 \mathrm{l} / \mathrm{s}$ must be possible in a kitchen, and extraction of at least $15 \mathrm{l} / \mathrm{s}$ and $10 \mathrm{l} / \mathrm{s}$ must be possible in a bathroom and a toilet room, respectively.

- In Estonia, the regulation expected for 2021 will require extraction rates of 6 1/s or $81 / \mathrm{s}$ for kitchen and 10 1/s or 15 1/s for bathroom, for 1-room and 2-or-more-room apartments respectively, and $10 \mathrm{l} / \mathrm{s}$ for the WC.

Dependent on the country, either a kitchen hood integration in MV is required or it has to work as a separate system, i.e. exhaust to the outside or just recirculation. However, some of the regulations do not address this issue as the EP regulation may address it instead.

The specific power input (SPI), as defined in Eco-design (Commission Delegated Regulation (EU) No 1254/2014), is a key metric for energy efficiency of air distribution system and the requirements for it are also reported in Table 2. The Belgian, French and Estonian legislations do not specify maximum values for SPI. However, the energy use by the ventilation fans is taken into account in the French and Belgian energy performance calculations, while in Estonia the recommendations for maximum SPI values are given in a guidebook for the design of nZEBs as the guidebook involves all aspects of nZEB design. 
Table 2. Summary of requirements to residential ventilation in new residences. Based on: ${ }^{1}$ OIB-Richtlinie 3 (2019), ${ }^{2}$ ÖNORM H 6038 (2014), ${ }^{3}$ NBN D 50-001 (1991), ${ }^{4}$ Energiebesluit 19/11/2010 (2010), ${ }^{5}$ BR18 (2019), ${ }^{6}$ Estonian legal acts 11.12 .2018 no. 63 (2018), ${ }^{7}$ Working draft for requirements for building indoor environmental quality and airing (2015), ${ }^{8}$ EVS-EN 16798-1:2019, ${ }^{9}$ Arrêté 24.03.82 (1983), ${ }^{10}$ Arrêté 26.10.2010 (2010), ${ }^{11}$ CCFAT (2015), ${ }^{12}$ TEK17 (2017), ${ }^{13} \mathrm{HM}$ Government (2010), ${ }^{14} \mathrm{BRE}$ (2012), ${ }^{15}$ The Scottish Government (2015). Legend: E\&W - England \& Wales, S - Scotland

\begin{tabular}{|c|c|c|c|c|c|c|c|}
\hline Country & Austria & Belgium & Denmark & Estonia & France & Norway & UK \\
\hline $\begin{array}{c}\text { Natural } \\
\text { ventilation } \\
(\mathrm{NV}) / \text { airing }\end{array}$ & Allowed & $\begin{array}{l}{ }^{3} \text { Allowed if } \\
\text { dedicated NV } \\
\text { system. Only } \\
\text { window airing NOT } \\
\text { allowed }\end{array}$ & ${ }^{5}$ Allowed & ${ }^{6}$ Allowed & $\begin{array}{l}{ }^{9} \text { Allowed but } \\
\text { rarely compliant } \\
\text { with }{ }^{10} \mathrm{EP} \\
\text { regulation for new } \\
\text { dwellings. }{ }^{9} \text { Only } \\
\text { window airing } \\
\text { NOT allowed }\end{array}$ & Allowed & $\begin{array}{l}{ }^{13} \underline{E} \& W: \text { Allowed } \\
{ }^{15} \underline{\mathrm{S}: \text { Not suitable if }} \\
\text { airtightness < } \\
5 \mathrm{~m}^{3} / \mathrm{h} / \mathrm{m}^{2}(50 \mathrm{~Pa})\end{array}$ \\
\hline $\begin{array}{c}\text { Mechanical } \\
\text { ventilation } \\
\text { (MV) }\end{array}$ & $\begin{array}{l}{ }^{1} \text { Only required if } \\
\text { NV cannot ensure } \\
\text { healthy IAQ }\end{array}$ & $\begin{array}{l}{ }^{3} \text { Recommended } \\
\text { only when } n_{50}<3 h^{-1} \\
\text { (MVHR } \\
\text { recommended only } \\
\text { if } n_{50}<1 h^{-1} \text { ) }\end{array}$ & $\begin{array}{l}{ }^{5} \mathrm{MVHR} \\
\text { recommended }\end{array}$ & $\begin{array}{l}{ }^{6} \text { MVHR promoted; } \\
\text { other ventilation } \\
\text { strategies allowed } \\
\text { if energy, IAQ and } \\
\text { thermal comfort } \\
\text { req. are met }\end{array}$ & $\begin{array}{l}\text { DCV-MEV or } \\
\text { MVHR required to } \\
\text { reach the target of } \\
\text { the }{ }^{10} \mathrm{EP} \text { regulation } \\
\text { for new dwellings. } \\
\text { MSV not allowed }\end{array}$ & $\begin{array}{l}{ }^{12} \mathrm{MVHR} \\
\text { recommended }\end{array}$ & $\begin{array}{l}13,15 \mathrm{MEV} \\
\text { MVHR } \\
\text { recommended }\end{array}$ \\
\hline Heat recovery & $\begin{array}{l}\text { None (local req. } \\
\text { to receive } \\
\text { subsidies) }\end{array}$ & $\begin{array}{l}{ }^{3} \text { Recommended } \\
\text { only when } \mathrm{n}_{50}<1 \mathrm{~h}^{-1}\end{array}$ & $\begin{array}{l}{ }^{5} \text { Required } \\
\text { Decentralized } \\
\geq 80 \% \text {; } \\
\text { Centralized } \geq 67 \%\end{array}$ & $\begin{array}{l}{ }^{6} \text { Not mandatory } \\
\text { but required to } \\
\text { fulfil energy req. }\end{array}$ & $\begin{array}{l}{ }^{9} \text { No requirement } \\
\text { but reward in the } \\
{ }^{10} \mathrm{EP} \text { calculation }\end{array}$ & $\begin{array}{l}{ }^{12} \text { Required } \\
\geq 80 \%\end{array}$ & $\begin{array}{l}{ }^{14} \text { Not mandatory } \\
\text { (recommended min. } \\
66 \% \text { ) }\end{array}$ \\
\hline $\begin{array}{l}\text { MV system } \\
\text { allowed to be } \\
\text { switched off }\end{array}$ & Not addressed & ${ }^{3}$ Not allowed & $\begin{array}{l}\text { Not allowed, } \\
\text { except outside } \\
\text { heating season if } \\
\text { nominal vent. rate } \\
\text { is ensured through } \\
\text { windows, air } \\
\text { valves, etc. }\end{array}$ & Not addressed & ${ }^{9}$ Not allowed & Not addressed & Not addressed \\
\hline $\begin{array}{c}\text { Kitchen hood } \\
\text { integration }\end{array}$ & $\begin{array}{l}{ }^{2} \text { Not integrated } \\
\text { into MVHR }\end{array}$ & ${ }^{3}$ Not addressed & $\begin{array}{l}\text { Not addressed; } \\
{ }^{5} \text { Mechanical and } \\
\text { adjustable kitchen } \\
\text { hood connected to } \\
\text { the outside } \\
\text { required }\end{array}$ & $\begin{array}{l}\text { Not addressed; } \\
{ }^{7} \text { Integration into } \\
\text { MVHR allowed; } \\
\text { Min. exhaust } 251 / \mathrm{s}\end{array}$ & $\begin{array}{l}\text { Not addressed in } \\
\text { the airing } \\
\text { regulation }{ }^{9} \text { but } \\
\text { kitchen hood other } \\
\text { than recirculation } \\
\text { rarely compliant } \\
\text { with }{ }^{10} \mathrm{EP} \\
\text { regulation }\end{array}$ & $\begin{array}{l}\text { Not addressed; } \\
{ }^{12} \text { Basic ventilation } \\
\text { rate } 36 \mathrm{~m}^{3} / \mathrm{h}\end{array}$ & $\begin{array}{l}\text { Not addressed; } \\
{ }^{13} \text { Min. exhaust } \\
30 \mathrm{l} / \mathrm{s} \text { (adjacent to } \\
\text { hob, intermittent) }\end{array}$ \\
\hline
\end{tabular}




\begin{tabular}{|c|c|c|c|c|c|c|c|}
\hline $\begin{array}{c}\text { Nominal } \\
\text { ventilation } \\
\text { rate* }\end{array}$ & $\begin{array}{l}{ }^{2} \text { Bedrooms: min. } \\
20 \mathrm{~m}^{3} / \mathrm{h} / \text { pers. } \\
\text { Living room: } \\
30 \mathrm{~m}^{3} / \mathrm{h} \text { (or } \\
15 \mathrm{~m}^{3} / \mathrm{h} / \text { pers.); } \\
\text { Overflowing air } \\
\text { can be accounted } \\
\text { for }\end{array}$ & $\begin{array}{l}33.6 \mathrm{~m}^{3} / \mathrm{h} / \mathrm{m}^{2} \text { for the } \\
\text { dry spaces, with } \\
\text { specific minimum } \\
\text { rates per type of } \\
\text { room }\end{array}$ & $\begin{array}{l}{ }^{5} 0.3 \mathrm{l} / \mathrm{s} / \mathrm{m}^{2} \text { heated } \\
\text { floor area }\end{array}$ & $\begin{array}{l}{ }^{6} \mathrm{SFH}: 0.42 \mathrm{l} / \mathrm{s} / \mathrm{m}^{2} \\
\left(\geq 120 \mathrm{~m}^{2}\right) \\
0.5 \mathrm{l} / \mathrm{s} / \mathrm{m}^{2}(<120 \\
\left.\mathrm{m}^{2}\right) \\
\text { MFH: } 0.5 \mathrm{l} / \mathrm{s} / \mathrm{m}^{2} \\
{ }^{7} \text { Bedroom, living } \\
\text { room: } \\
>15 \mathrm{~m}^{2}: 14 \mathrm{l} / \mathrm{s} ; \\
\leq 15 \mathrm{~m}^{2}: 12 \mathrm{l} / \mathrm{s} ; \\
\text { Bedroom: } \\
<11 \mathrm{~m}^{2}: 8 \mathrm{l} / \mathrm{s}\end{array}$ & $\begin{array}{l}{ }^{9} \text { Function of } \\
\text { number of main } \\
\text { rooms and wet } \\
\text { rooms ( } 3 \text { rooms: } \\
30 \mathrm{~m}^{3} / \mathrm{h} \text { in } \\
\text { bathroom, } 15 \mathrm{~m}^{3} / \mathrm{h} \\
\text { in other wet rooms, } \\
45 \mathrm{~m}^{3} / \mathrm{h} \text { with } \\
\text { possibility to } \\
\text { increase to } 105 \\
\mathrm{~m}^{3} / \mathrm{h} \text { in kitchen) }\end{array}$ & $\begin{array}{l}121.2 \mathrm{~m}^{3} / \mathrm{h} / \mathrm{m}^{2} \text { (in } \\
\text { use) } \\
\text { (bedroom at least } \\
26 \mathrm{~m}^{3} / \mathrm{h} / \text { pers. when } \\
\text { in use) }\end{array}$ & $\begin{array}{l}{ }^{13} \underline{E \& W}: \min .0 .3 \\
1 / \mathrm{s} / \mathrm{m}^{2} \text { floor } / \mathrm{n} . \text { of } \\
\text { bedrooms }(3 \\
\left.\text { bedrooms: } 76 \mathrm{~m}^{3} / \mathrm{h}\right) \\
\text { S: spec. by } \min . \\
\text { area of vent. } \\
\text { opening }\end{array}$ \\
\hline $\begin{array}{c}\text { Minimum } \\
\text { ventilation } \\
\text { rate* }\end{array}$ & $\begin{array}{l}{ }^{2} \mathrm{Min} . \mathrm{ACH}=0.15 \\
\text { required during } \\
\text { non-occupancy }\end{array}$ & $\begin{array}{l}{ }^{4} \mathrm{DCV}: \text { never below } \\
10 \% \text { of the nominal } \\
\text { flow rate }\end{array}$ & $\begin{array}{l}{ }^{5} \text { Min. } 0.31 / \mathrm{s} / \mathrm{m}^{2} \\
\text { heated floor area }\end{array}$ & $\begin{array}{l}{ }^{8} 0.05-0.11 / \mathrm{s} / \mathrm{m}^{2} \\
\text { during non- } \\
\text { occupancy } \\
{ }^{6} \mathrm{DCV} \text { : min. } 0.15 \\
1 / \mathrm{s} / \mathrm{m}^{2} \text { during } \\
\text { occupancy }\end{array}$ & $\begin{array}{l}{ }^{9} \text { Function of } \\
\text { number of "main } \\
\text { rooms" ( } 3 \text { rooms } \\
\text { min. } 75 \mathrm{~m}^{3} / \mathrm{h}, 15 \\
\left.\mathrm{~m}^{3} / \mathrm{h} \text { if } \mathrm{DCV}\right)\end{array}$ & $\begin{array}{l}{ }^{12} \text { Min. } 0.7 \mathrm{~m}^{3} / \mathrm{h} / \mathrm{m}^{2} \\
\text { during non- } \\
\text { occupancy }\end{array}$ & $\begin{array}{l}{ }^{13} \text { Min. } 0.3 \mathrm{l} / \mathrm{s} / \mathrm{m}^{2} \\
\text { internal floor area }\end{array}$ \\
\hline $\begin{array}{l}\text { SPI (specific } \\
\text { power input) }\end{array}$ & ${ }^{2} \leq 1.62 \mathrm{~kW} /\left(\mathrm{m}^{3} / \mathrm{s}\right)$ & $\begin{array}{l}{ }^{4} \text { No requirement but } \\
\text { reward in the EP } \\
\text { calculation }\end{array}$ & $\begin{array}{l}{ }^{5} \text { System for one } \\
\text { residential unit } \leq \\
1000 \mathrm{~J} / \mathrm{m}^{3} ; \\
\text { System for multi- } \\
\text { storey residential } \\
\text { units } \leq 1500 \mathrm{~J} / \mathrm{m}^{3} \text {; } \\
\mathrm{MEV} \leq 800 \mathrm{~J} / \mathrm{m}^{3}\end{array}$ & $\begin{array}{l}\text { No mandatory; } \\
\text { Recommendation } \\
\text { for } n Z E B \\
\text { ventilation design } \\
\leq 1.5 \mathrm{~kW} /\left(\mathrm{m}^{3} / \mathrm{s}\right)\end{array}$ & $\begin{array}{l}{ }^{9} \text { No requirement } \\
\text { but reward in the } \\
{ }^{10} \mathrm{EP} \text { calculation }\end{array}$ & ${ }^{12} \leq 1.5 \mathrm{~kW} /\left(\mathrm{m}^{3} / \mathrm{s}\right)$ & $\begin{array}{l}{ }^{14} \text { Recommended } \\
\text { values: } \\
\mathrm{MEV} \leq 0.8 \\
\mathrm{~kW} /\left(\mathrm{m}^{3} / \mathrm{s}\right) \\
\text { Balanced whole- } \\
\text { house } \mathrm{MV} \leq 2.0 \\
\mathrm{~kW} /\left(\mathrm{m}^{3} / \mathrm{s}\right)\end{array}$ \\
\hline Controls & $\begin{array}{l}{ }^{2} \mathrm{DCV} \\
\text { recommended; } \\
\text { Min. } 3 \text { levels for } \\
\text { fan speed required }\end{array}$ & $\begin{array}{l}{ }^{3} \text { All types of } \\
\text { controls allowed } \\
\text { that do not } \\
\text { completely shut } \\
\text { down the } \\
\text { mechanical parts. } \\
{ }^{4} \text { Types of DCV } \\
\text { addressed only in } \\
\text { the EPB regulations }\end{array}$ & $\begin{array}{l}{ }^{5} \text { DCV may be } \\
\text { used; Background } \\
\text { vent. rate has to be } \\
\text { ensured }\end{array}$ & $\begin{array}{l}{ }^{6,7} \mathrm{DCV} \text { may be } \\
\text { used } \\
{ }^{7} \mathrm{Background} \text { vent. } \\
\text { rate has to be } \\
\text { ensured and } \mathrm{CO}_{2}< \\
1200 \mathrm{ppm} \text {; } \\
\text { if } \mathrm{RH}>65 \% \text { in } \\
\text { wet rooms, the } \\
\text { min. extract vent. } \\
\text { rates must be met }\end{array}$ & $\begin{array}{l}{ }^{11} \mathrm{DCV} \text { often used } \\
\text { and must go } \\
\text { through an } \\
\text { agreement } \\
\text { procedure with } \\
\text { IAQ performance } \\
\text { indicators }\left(\mathrm{CO}_{2}\right. \\
\text { cumulative } \\
\text { exposure and } \\
\text { condensation risk) }\end{array}$ & Not addressed & $\begin{array}{l}{ }^{13} \mathrm{DCV} / \text { manual; } \\
\text { RH contr. req. in } \\
\text { wet rooms; Trickle } \\
\text { ventilators } \\
\text { controlled by } \\
\text { occupants }\end{array}$ \\
\hline
\end{tabular}

*Nominal and minimum ventilation rates are shown in the units stated in the specific national regulations. Minimum ventilation rates are the minimum required airflows to be ensured at any time -

for some countries specified as background ventilation or as minimum required ventilation rates during non-occupancy time. 


\subsection{Review of guidelines for practitioners}

The IEA EBC Annex 68 participants reviewed altogether 33 guidelines for practitioners from seven countries: Austria (3), Belgium (2), Denmark (6), Estonia (2), France (12), Norway (1) and the United Kingdom (7). Target groups are mostly heating, ventilation and air-conditioning (HVAC) engineers, consultants, architects, housing developers, the construction industry and private owners. In the case of the two Belgian guidelines the main target group is ventilation installers, but the guidelines indicate HVAC engineers, consultants and architects as potentially interested. Only guides from France and the UK are directed to facility managers. The referred material has a focus on newly-built and renovated buildings covering both single-family houses and apartment buildings. The reviews from France, Norway and the UK include guidance regarding high-rise apartment buildings. More than half of the guides provide guidance with respect to legislative requirements. Most guides are available in both printed and online versions and include references to further sources of information. The French guidelines do not recommend any specific ventilation system rather providing guidance and information about all possible systems, their features, installation, etc. Moreover, they describe qualitative approaches to air quality in residences. In the case of the other countries, the guidelines mostly recommend balanced mechanical ventilation with heat recovery. One Estonian, one Danish and four guides from the UK provide additional recommendations about hybrid ventilation. Four publications from the UK also give recommendations regarding NV. There are three notable guidelines: a Danish guideline providing recommendations regarding input parameters to be used in building simulations tools (Vorre et al., 2017), an official guide for installers serving as reference for 'good practice' from Belgium (Caillou et al., 2016), and a Belgian brochure structured in 11 steps to achieve a good, comfortable and energy efficient ventilation system (Van den Bossche et al., 2007).

\subsection{Stakeholder survey}

The results from the stakeholder survey presented in the article are based on a total number of 44 interviews performed in 2017 in: Austria (6), Belgium (10), Denmark (5), Estonia (4), France (5), Norway (7) and the UK (7). Table 3 shows the number of people from each stakeholder group participating in the survey with years of stakeholder's experience in the field indicated in the subscript. At least 24 of the interviewees had minimum 10 years of experience in the field/industry.

Table 3. Numbers of interviews performed in each of the countries with indication of years of stakeholder's experience in the field/industry.

\begin{tabular}{cccccccc}
\hline Country & Austria & Belgium & Denmark & Estonia & France & Norway & UK \\
\hline $\begin{array}{c}\text { Ventilation } \\
\text { designers } \\
\text { \& Consultants }\end{array}$ & $2_{(21,23)}$ & $4_{(1,9,14,15)}$ & $4_{(4,8,20, \mathrm{~N} / \mathrm{A})}$ & $1_{(35)}$ & $2_{(9, \mathrm{~N} / \mathrm{A})}$ & $2_{(9,9)}$ & $2_{(10,14)}$ \\
\hline $\begin{array}{c}\text { Building } \\
\text { administration }\end{array}$ & & $2_{(11,23)}$ & $1_{(25)}$ & & & \\
\hline $\begin{array}{c}\text { Public } \\
\text { authorities }\end{array}$ & $1_{(15)}$ & $2_{(6,13)}$ & $1_{(6)}$ & $2_{(14,10)}$ & $2_{(15, \mathrm{~N} / \mathrm{A})}$ & $1_{(20)}$ \\
\hline $\begin{array}{c}\text { Housing } \\
\text { developers }\end{array}$ & $2_{(15,40)}$ & & & & $3_{(20)}$ & $3_{(19,22, \mathrm{~N} / \mathrm{A})}$ \\
\hline $\begin{array}{c}\text { Producers of } \\
\text { ventilation } \\
\text { systems }\end{array}$ & $1_{(36)}$ & $2_{(10,6)}$ & $1_{(\mathrm{N} / \mathrm{A})}$ & $1_{(6)}$ & $1_{(5)}$ & & $1_{(3)}$ \\
\hline
\end{tabular}

( ) - stakeholder's years of experience in the field/industry

N/A - information not available

The new versions of the building codes in Denmark and Norway came into force since the stakeholder survey was performed. However, the requirements to ventilation and indoor air 
quality remained unchanged. In the following analysis, the original references to the requirements mentioned by the stakeholders are reported.

\subsubsection{Mechanical ventilation - current practice}

This chapter reports the information about practice in design and operation of mechanical ventilation system in residences gathered in the interviews. The presentation of the information follows the questions listed in Table 1.

\section{Type of systems}

With respect to types of ventilation systems (Questions a and b in Table 1), the interviews revealed that MV systems are dominant, in most countries with heat recovery. However, there are variations in all countries.

The majority of the stakeholders provided information regarding multi-family houses (MFH), where the apartments range from 20 to $200 \mathrm{~m}^{2}$. Regarding single-family houses (SFH), the only provided information on the size was from France with the range between $90-110 \mathrm{~m}^{2}$. The Belgian stakeholders did not specifically address the dwelling type.

In Austria, natural ventilation and mechanical exhaust (MEV) systems are receiving comparable attention. For example, one HVAC planner in the province of Vorarlberg stated that they used to have a legal requirement to build all publicly built housing according to the Passive House (PH) standard, which required MVHR ventilation. After removing this requirement, implementation of MVHR dropped drastically and most new housing projects in that province installed a simple extract air system or solely relied on NV. That planner explained that "Non-public housing developers were put in a tight spot" having to argue why social housing had "higher standard" than their buildings. He added that the situation was distorted due to the housing subsidies received by the social housing developers and that consequently the private constructors were able to promote their views that MVHR ventilation is questionable and capital and operation costs are too high. At the same time, a designer referred to an Austrian research project (Ploß, 2016), which showed that $70 \%$ of the 55 most economic building design variants (based on lifecycle costs) were with MVHR, the rest with MEV. Since the cost differences between these 55 variants were negligible, his opinion was that the solution with the higher comfort should be prioritized. Another designer stated that ventilation with manually operable windows or MEV systems are applied in projects that do not aim for any public subsidy.

In Belgium, NV (system A) is barely applied due to problems with achieving the required airflows. MSV (system B) is not popular for practical reasons and due to concerns with moisture management of the façade in a pressurised dwelling. MEV (system C) is being pushed out of the market by MVHR (system D) in low energy dwellings. However, it is still installed in many new apartments and dwellings, and it is commonly used in renovated constructions. All Belgian stakeholders emphasised advantages of MVHR compared to MEV, except one facility manager who recommended MEV as the best solution for apartment buildings due to lack of space for ducts and lower installation, operation and maintenance cost. In case of MEV, electrical resistance in window grills is sometimes used to prevent cold draught. Most of the Belgian stakeholders mentioned DCV MEV as the dominant type of MEV, having low electricity demand and therefore able to follow the energy performance requirements. However, the price of such system catches up with the one for system $D$, especially if equipped with many sensors. The Belgian energy performance regulations do not yet approve a hybrid system, i.e. periodical 
switch between natural and mechanical ventilation. One of the Belgian ventilation producers said that their MVHR units are prepared to switch off the supply fan in summer to work as MEV. DCV MEV with a heat pump was mentioned as a solution to recover heat from the extracted air to be further used for low temperature heating and preparation of domestic hot water. The interviewees pointed out that the three regions in Belgium: Brussels Capital Region, Flemish Region and Walloon Region have the same general requirements for ventilation, but differences in nuances and practice may occur.

In France exhaust-only, humidity-based DCV systems including humidity-sensitive trickle ventilators and extract devices seem to be the state of the art in new (low-energy) residential buildings.

The dominance of MVHR systems is obvious in Scandinavian countries and for dwellings with air permeability lower than $5 \mathrm{~m}^{3} / \mathrm{h} / \mathrm{m}^{2}(50 \mathrm{~Pa})$ in the UK. The stakeholders from these countries commonly mentioned the maintenance issue.

Generally, centralized air handling systems are often mounted in social apartments, because inhabitants are not interested in maintaining a decentralized system and it is more expensive to service several individual units.

\section{Other appliances influencing ventilation}

The results of the survey show that other appliances that influence ventilation (Question $\mathrm{c}$ in Table 1) are mostly taken into account. The interviewees from Estonia mentioned separate exhaust system design for kitchen hoods. None of the Austrian stakeholders pointed out integrated solutions for kitchen hoods, but most respondents referred to the use of recirculating hoods. In contrast to that, the Norwegian stakeholders noted that it is common to connect the kitchen hood to the ventilation system. Where a separate fan is used, the pressure-sensor is applied to ensure balanced ventilation. The Danish designers also referred to integration of the kitchen hood and consequent boost of a supply fan to provide balanced ventilation as a viable technical solution. An argument for integration of kitchen hoods was optimal functioning of heat recovery. However, one of the Danish designers had an opposite opinion, noting that grease from cooking may pollute the system. The Belgian stakeholders referred to all three solutions for kitchen hoods, however, prioritised separate systems. In case of a kitchen hood extracting directly to the outside, all Belgian stakeholders pointed out a need for an additional opening in the building envelope for balancing the airflows. However, one of the stakeholders stated that it is very seldom done in practice.

\section{Heat recovery}

A counter-flow plate heat exchanger is mostly used for heat recovery (Question $\mathrm{d}$ in Table 1), followed by a cross-flow heat exchanger. The stakeholders mentioned rotary heat exchangers only in connection to decentralized ventilation units. Rotors can potentially transfer condensable odorous substances (e.g. from cooking), so in a centralized system in an apartment building there would be a risk of "smelling a neighbour's lunch". Within one dwelling, a small potential odour transmission (e.g. into a bedroom) is not considered to be a problem. Heat recovery is not required in the Belgian building regulations. However, balanced MV systems (system D) without heat recovery are no longer installed or found on the Belgian market, which could be indicative of the effect of energy regulations on provision of ventilation systems. The building regulations in some countries such as the UK do not cover installation of summer bypass mode for MVHR. It can lead to overheating if designers and system suppliers do not specify this measure. 


\section{Air distribution}

The stakeholders addressed in varying details the efficiency of delivering air into rooms (Question e in Table 1). Some described quite precisely their strategy for air distribution, while others were less precise and just mentioned mixing ventilation. When designing/implementing balanced systems in Austria, the so-called extended cascade systems seem to be preferred (Rojas et al., 2015). A designer stated that if possible and the floor plan allows for that, the living room is purely treated as an overflow zone, reducing the total number of supply air terminals and supply air rate. The Norwegian, Danish, Belgian, French and the UK designers stated that in their systems fresh air is supplied into bedrooms and living rooms and extracted from bathrooms, toilets and kitchens (i.e. a cascade system). A French designer pointed out two important aspects regarding MEV and MVHR systems. In the case of mechanical exhaust in a tight building, it is necessary to ensure dedicated openings in the building envelope for air supply. In the case of balanced systems, a tight ductwork is necessary.

\section{Type of control}

Considering the prevailing type of control (Question $\mathrm{f}$ in Table 1), application of DCV appears to be rare in the countries participating in the survey, except in France and Belgium. Other studies have found that other European countries such as the Netherlands, Poland and Spain are using DCV systems (Guyot et al., 2018). A designer from Austria noted that DCV for residential housing sector does not prevail on the market as the higher costs come into effect. This designer also mentioned technical problems with positioning of sensors and stated that the only reasonable approach is to place a sensor in each room. This, however, increases both cost and complexity of the system. In France, the reference ventilation system in new (low-energy) residential buildings is a humidity-based DCV including fully-mechanical air inlets in the dry rooms and exhaust units in the wet rooms (the extensions and retractions of a hygroscopic fabric modify the outlet cross-section upon hygrometric changes in its environment). A French producer named different types of systems and mentioned that when balanced ventilation is used, airflows are constant and occupants have possibility to boost the kitchen exhaust unit. Typical control consists of a user-operated switch that allows changing the amount of supplied air in relation to the user activity in a dwelling: "away", "normal occupation", "party", etc. A Norwegian housing developer also mentioned the possibility to adjust the airflow manually in three levels by the user in decentralized systems, while in the case of centralized systems, occupants seldom could do any adjustments. Another Norwegian housing developer confirmed the previous statement, but added that there can be a switch on the kitchen hood and an "indirect control" in a bathroom, either a humidity-controlled valve or an on/off switch. A ventilation producer from Estonia pointed out centralized control. Both developers and designers from the UK mentioned manual switch or humidity-based boost modes for ventilation control in bathrooms and kitchens. They also mentioned that users can switch their system off, but they are encouraged by developers and installers not to do so. This topic seems also to be important for Danish designers who pointed out that even if a system has a simple "on/off" control, the off does not actually mean that there is no airflow through the system, as this is not allowed according to the building regulations. Based on the survey in Belgium, it seems that in case of $\mathrm{MV}$, systems with constant air volume flow (CAV) are the most common solution for apartments, while systems with variable air volume flow (VAV) based on $\mathrm{CO}_{2}$ or moisture sensors are rather seldom installed. A typical DCV MEV system is equipped with motion and/or moisture sensors in wet spaces, while more advanced systems also have $\mathrm{CO}_{2}$ sensors in dry spaces. Occupants can influence the airflows only in case of decentralized ventilation units (typically 3 levels of fan speed). 


\section{Minimum airflows}

Answers to the question regarding minimum required ventilation rates and IAQ in dwellings (Question $g$ in Table 1) indicated that the stakeholders were mostly aware of the lower limits for ventilation airflows imposed by particular building codes. The Austrian building code (OIBRichtlinie 3, 2015) includes general statements on required ventilation for rooms where people reside and for sanitary rooms. The building code does not provide any explicit values regarding air exchange rate, supply or exhaust airflows, but there is a reference to a standard dealing in detail with ventilation plants (ÖNORM H 6038, 2014). Several stakeholders from Austria mentioned a building certification program launched by the Austrian ministry ("klimaaktiv"), which includes measures to improve IAQ (e.g. system efficiency and filters). Extra points are given within the subsidy application if this "klimaaktiv" certification is done. In the case of Denmark, the stakeholders stated that there is not a clear standard about indoor air requirements and that the documents available are outdated. This is a rather interesting feedback, because the Danish building code (BR15, 2017) and related standards specifically mention IAQ. The building regulations deal with general requirements for IAQ and in addition refer to specific pollution sources such as formaldehyde. There is no regulation specifically concerning air humidity in Danish dwellings. The ventilation designers in France stated that no IAQ classification schemes, guidelines or standards are applied, only exhaust airflow requirements and rules for air inlet sizing according to DTU 68.3 (2017). Minimum extract airflows are given for each type of a wet room depending on the total number of normal rooms. In Norway, the stakeholders reported that the national standard, TEK10 (2010), determines minimum airflows regarding materials and number of persons. For non-occupied spaces, only minimal ventilation rate is required. In addition, a technical guideline, developed by the Norwegian Building Research Institute (Bøhlerengen, 2017), was used to show examples of ventilation requirements defined in TEK10 (2010). Approved Document Part F: Means of ventilation (HM Government, 2010) and the Domestic Technical Handbook of the Scottish Building Regulations (The Scottish Government, 2015) are the IAQ standards used for ventilation in England and Wales, and Scotland, respectively. One of the UK respondents mentioned that IAQ is not a design priority outside major cities i.e. only a basic and cost-effective design is provided to comply with the regulations. He noted that more attention is paid to the other aspects of the design that are more pertinent in a given context. The Belgian stakeholders pointed out that it is a requirement to provide a ventilation report after a building has been in operation for 6 months. This ensures proper design and implementation of the ventilation system as well as measured airflows follow the Belgian energy performance regulations and the Belgian building code (NBN D 50-001, 1991). It was also stated that in the Walloon Region the concept of a ventilation system has to be approved in advance, while in the Flemish Region only the post installation approval is required.

\section{Ductwork}

The answers to the question regarding the type of ducting used for MV in residences (Question $\mathrm{h}$ in Table 1) showed that the Austrian, Danish, Estonian, French and Norwegian designers typically use circular steel galvanized ducts. Occasionally, more expensive rectangular steel ducts are mounted where space is limited. Flexible plastic tubing integrated in concrete slabs can also be found on the Austrian market. In the UK, rectangular and flat oval plastic ducts are common choice since these ducts maximize the floor-to-ceiling height and are cheaper than steel ducts. In Belgium, plastic and galvanized steel circular and oval ducts are the state of the art.

In Denmark, a constructor is responsible to test the leakage of ducts (Question i) according to the Danish standard for designing, installation, operation, maintaining and commissioning of mechanical, natural and hybrid ventilation systems in buildings, including dwellings - DS 
447:2013 and based on recommendations from a ventilation designer. However, one of the Danish designers revealed that the ducts are not always tested for leakages, especially when a trustworthy company makes the installation of the system. Two of Belgian designers also reported that the tightness of ducts in residential ventilation systems is almost never tested. The common use of "spiro safe" (double lip seal) in Austria does not require testing airtightness. Estonian and French designers stated that the test is performed according to EN 12237:2003 specifying requirements and test methods for strength and air leakage of circular ductwork used in air conditioning and ventilation systems in buildings.

Based on the interviews from all seven countries it can be concluded that it is a common practice to place silencers at supply and extract ducts from air handling units (AHUs) (Question j). The designers from Denmark, Norway and Austria mentioned the use of additional silencers between rooms. The Danish designers also recommended silencers at extract ducts from bathrooms and kitchens.

\section{Filters}

The designers from Austria, Norway and Belgium mentioned filtration class F7 for the ambient air in residential MV (Question k in Table 1). One of the Belgian designers referred to the same filtration class also for extracted air. However, two Belgian producers of ventilation systems stated that their standard AHUs for MVHR are equipped with G4 filters with the possibility to be exchanged to F7, if requested. One of these producers added that in their new generation of AHUs, filter F7 is a standard equipment. Both Austrian and Belgian producers pointed out that their AHUs have filter G4 for the extract air. A ventilation installer from Belgium indicated that his company is the only one with experience of using electrostatic filters, and referred to a case where such filter was installed in a residence close to a pig farm.

\section{Frost protection}

One of the designers reported frost protection in residential MV systems (Question 1 in Table k) as seldom used in the UK, while another stakeholder mentioned electrical frost protection integrated in AHUs. Preheating of the ambient air seems to be a common practice in Austria both solutions with an electric preheater and a heating coil connected to a heating system (water-based, ground heat pump or solar thermal system). The Danish designers referred to various solutions: a heating coil before the AHU connected to a water-based heating system, an electric preheater (especially in decentralized systems) or a bypass on the system to increase exhaust compared to supply (a possible solution in renovated buildings, not applicable in tight buildings). Contrarily, another designer never designs with pre-heating before AHUs. The solution for frost protection reported by the Norwegian designer was an electrical heating element integrated in AHU and controlled by a temperature sensor. The French designer referred to another solution whereby the supply airflows are simply stopped or reduced for a short period for frost protection.

\subsubsection{Barriers and problems}

The barriers and problems identified in this survey were categorized based on a building's procurement stages: design, construction (installation and commissioning) and post-handover, as shown in Table 4 . The number of times each item was raised in the interviews in each country is provided in Table 4 as frequency of occurrence. The identified problems are listed in descending order of frequency.

During the design phase, the investment required to provide whole-house mechanical ventilation along with spatial and maintenance requirements of these systems are among key concerns. For MVHR systems specifically, several stakeholders pointed out that the capital cost 
is notably higher than for conventional ventilation systems. The conventional systems were defined as the mostly used systems in each country, such as extract air ventilators in humid rooms, exhaust-only or natural ventilation. Furthermore, MV requires more space and duct routing, which can be challenging in general and even more in building renovation. After the decision making process, the lack of proper and detailed ventilation design was pointed out as problematic. One interviewee also raised other potential difficulties: positioning the units to minimise noise, finding an appropriate location for ambient air intake, and fire safety requirements for centralized ventilation in apartments.

Non-compliance with regulatory requirements due to poor system installation and quality or lack of commissioning were raised as common issues during construction. Indeed, several interviewees noted shortcomings in the skillset of installers who are often not up to date regarding the latest ventilation and energy efficiency requirements. The lack of training was also highlighted together with the complexity of some systems.

System maintenance and operation after building handover was a key problem raised in most countries. Lack of clear instructions about system operation and maintenance requirements, in user manuals and during building handover, including the change of filters, was a major issue. Accessibility is also a key consideration for decentralised systems where MVHR units are installed inside apartments and access for regular maintenance might be difficult. In addition, interviewees reported that unless there is a follow-up service contract in place, which is mostly applicable to apartment blocks with centralised systems, key maintenance requirements may not be met in practice as occupants are not well briefed about these requirements and the consequences of poor maintenance. Noise and perceived cost of operation, which in extreme cases had led to occupants turning their systems off, were among other problems identified in the survey. These issues will be further discussed in the next section about MV acceptability. 
Table 4. Barriers against and problems associated with mechanical ventilation of low-energy dwellings identified in the survey.

\begin{tabular}{|c|c|c|c|}
\hline $\begin{array}{c}\text { Country } \\
\text { (interviews) }\end{array}$ & $\begin{array}{c}\text { Design } \\
\text { (decision making, concept design \& detail design) }\end{array}$ & $\begin{array}{c}\text { Construction } \\
\text { (installation \& commissioning) }\end{array}$ & $\begin{array}{c}\text { Post-handover } \\
\text { (operation \& maintenance) }\end{array}$ \\
\hline $\begin{array}{c}\text { Austria } \\
(6)\end{array}$ & $\begin{array}{l}\text { High capital cost of MVHR systems (4) } \\
\text { Spatial requirements \& duct routing (3) } \\
\text { Implementation in refurbishments particularly challenging (2) } \\
\text { Lack of flexibility for flow rates to account for real occupancy } \\
\text { (1) } \\
\text { Prejudice against MV systems (1) }\end{array}$ & $\begin{array}{l}\text { Lack of up to date training and } \\
\text { skills among system installers (1) }\end{array}$ & $\begin{array}{l}\text { Noise especially in decentralised systems (4) } \\
\text { System maintenance \& access (2) } \\
\text { Re-programming of the systems (1) } \\
\text { No proper support for tenants (1) }\end{array}$ \\
\hline $\begin{array}{l}\text { Belgium } \\
\text { (10) }\end{array}$ & $\begin{array}{l}\text { Spatial requirements and/or duct routing ( } 8) \\
\text { Coordination between HVAC planer, architect and/or customer } \\
\text { (5) } \\
\text { Positioning exterior in-/outlets (2) } \\
\text { Lack of knowledge (1) }\end{array}$ & $\begin{array}{l}\text { Lack of qualified/experienced } \\
\text { installers and lack of quality (2) } \\
\text { Implementation in refurbishments } \\
\text { particularly challenging (1) } \\
\text { Adjustment of flowrates (1) }\end{array}$ & $\begin{array}{l}\text { Lack of occupant knowledge/awareness (1) } \\
\text { Maintenance issues (4) } \\
\text { Draughts/covering grids (2) } \\
\text { Noise (2) } \\
\text { Dry air (1) } \\
\text { Odour from outside (1) }\end{array}$ \\
\hline $\begin{array}{c}\text { Denmark } \\
(5)\end{array}$ & $\begin{array}{l}\text { Spatial requirements \& duct routing (4) } \\
\text { High capital cost of MVHR systems (2) } \\
\text { Fire safety requirements for centralized vent. in apartments (1) } \\
\text { Stringent energy efficiency requirements (1) } \\
\text { Working with architect's design (2) }\end{array}$ & $\begin{array}{l}\text { Designers are often not involved } \\
\text { in commissioning (1) } \\
\text { Big centralised systems become } \\
\text { too complicated (1) } \\
\text { Proper commissioning is rare (1) }\end{array}$ & $\begin{array}{l}\text { Maintenance issues (3) } \\
\text { Occupants block the inlets distorting air balance (1) } \\
\text { Poor support \& aftercare for users (1) } \\
\text { No proper support for tenants (1) }\end{array}$ \\
\hline $\begin{array}{c}\text { Estonia } \\
\text { (4) }\end{array}$ & $\begin{array}{l}\text { Spatial requirements \& duct routing (1) } \\
\text { Challenging frost protection (1) } \\
\text { Cost \& technical complexity especially in renovating old } \\
\text { buildings (1) }\end{array}$ & & $\begin{array}{l}\text { Noise (2) } \\
\text { Operational failures (2) } \\
\text { Cold draughts (1) } \\
\text { Smells/odour (1) } \\
\text { No proper support for tenants (1) }\end{array}$ \\
\hline $\begin{array}{l}\text { France } \\
(5)\end{array}$ & $\begin{array}{l}\text { High capital cost of MVHR (2) } \\
\text { Maintenance requirements of MVHR (1) } \\
\text { Complexity of MVHR compared to exhaust-only humidity- } \\
\text { based DCV (1) } \\
\text { Spatial requirements for MVHR (1) } \\
\text { Design acceptability (1) } \\
\text { Lack of project-specific design/planning (2) }\end{array}$ & $\begin{array}{l}\text { Poor quality in system installation } \\
\& \text { commissioning ( } 3) \\
\text { Non-compliance with technical } \\
\text { requirements (2) }\end{array}$ & $\begin{array}{l}\text { Lack of maintenance (1) } \\
\text { Lack of change of filters (1) }\end{array}$ \\
\hline $\begin{array}{c}\text { Norway } \\
\text { (7) }\end{array}$ & $\begin{array}{l}\text { Spatial requirements \& duct routing (6) } \\
\text { Difficult to position the units to minimise noise (1) } \\
\text { Difficult to find an appropriate location for air intake (1) }\end{array}$ & $\begin{array}{l}\text { Designers are often not involved } \\
\text { in commissioning (1) } \\
\text { Systems not balanced (1) }\end{array}$ & $\begin{array}{l}\text { Maintenance issues, incl. filters (3) } \\
\text { No follow-up service arrangement (1) } \\
\text { Noise (1) }\end{array}$ \\
\hline
\end{tabular}




$\begin{array}{llll}\text { UK } & \text { Difficult to position the units to minimise noise (1) } & \text { Installation and commissioning } & \text { Maintenance issues (3) } \\ \text { not in accordance with design } & \text { Noise and perceived energy cost (tenants switch the } \\ \text { Spatial requirements \& duct routing (1) } & \text { intent (3) } & \text { Insufficient skills of installers (1) } \\ \text { Coordination with all design stakeholders (1) } & \text { Balancing the flow rates only, } \\ & \text { No minimum requirements for some pollutants in the } & \text { with less attention to pressure } \\ \text { regulations (1) } & \text { drop (1) } \\ & \text { Costs (1) } & & \\ & \text { No control over emission sources introduced by occupants (1) } & \end{array}$




\subsubsection{Potential for improvements}

Legislative pushes: Table 5 lists the key legislative requirements and improvement opportunities identified by the stakeholders, which could push mechanical ventilation implementation and enhance its performance. The key emerging themes are as follows:

- Calls for more flexibility in legislation, codes and building standards including a more holistic approach that allows for trade-offs

- The necessity for a coordinated approach to energy efficiency and IAQ

- Control mechanisms required to ensure good implementation and operation.

Currently, the responsibility for maintenance of mechanical ventilation systems in dwellings is not well-defined (e.g. MVHR filter replacement). A respondent in France suggested that building owners could be made accountable for regular maintenance of MVHR systems similar to the existing mandatory requirements for maintenance of heating systems in France and most European countries, where building owners are legally responsible for annual service and maintenance of these systems.

Table 5. Potential improvements in legislation and standardization expressed in this survey.

\begin{tabular}{|c|c|}
\hline Country & Improvement opportunities in legislation and standardization \\
\hline Austria & 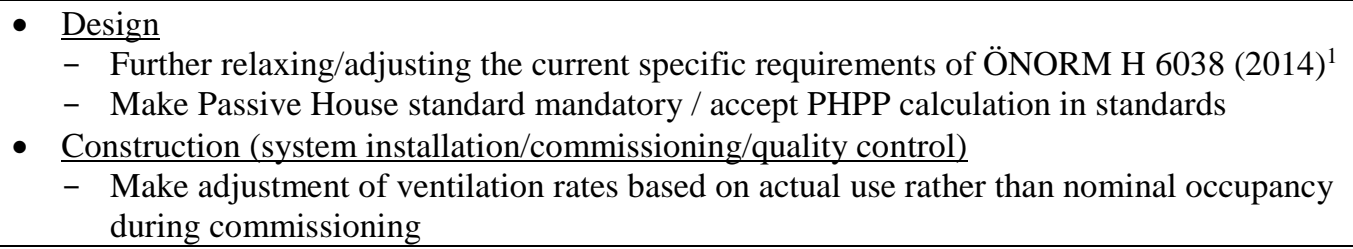 \\
\hline Belgium & $\begin{array}{l}\text { - Design } \\
- \text { More flexibility in European standard to account for specific regional differences } \\
-\quad \text { Some harmonisation between countries, being careful with 'one size fits all' solutions } \\
\text { - Construction (system installation/commissioning/quality control) } \\
- \text { Quality assurance program / more enforcement }{ }^{2} \\
- \text { Proactive rather than reactive quality control, e.g. putting requirements in contract rather } \\
\text { than just measurement report after building completion }\end{array}$ \\
\hline Denmark & $\begin{array}{l}\text { - Design } \\
\text { - Update/improve the IEQ standards for dwellings } \\
- \text { Set out requirements for ventilation control } \\
\text { Construction (system installation/commissioning/quality control) } \\
\text { - Set out detailed commissioning requirements } \\
\text { Post-handover (operation \& maintenance) } \\
-\quad \text { Strengthen requirements for training of maintenance/operation personnel and for training } \\
\quad \text { material }\end{array}$ \\
\hline Estonia & $\begin{array}{l}\text { - Construction (system installation/commissioning/quality control) } \\
- \text { Need for a control mechanism to ensure compliance with requirements } \\
\text { - Post-handover (operation \& maintenance) } \\
- \text { Define legislative requirements for system maintenance in apartments }\end{array}$ \\
\hline France & $\begin{array}{l}\text { - Design } \\
\text { - IAQ should get same priority as energy performance } \\
\text { - Construction (system installation/commissioning/quality control) } \\
\text { - Verification of ventilation performance at commissioning stage } \\
\text { - } \frac{\text { Post-handover (operation \& maintenance) }}{- \text { Mandatory requirements for maintenance of ventilation systems }} \\
\end{array}$ \\
\hline Norway & $\begin{array}{l}\text { - Design } \\
- \text { More options in the design phase regarding the requirements for energy efficiency and } \\
\text { indoor air quality, i.e. allow for natural ventilation in new dwellings } \\
-\quad \text { Promote assessment methods such as BREEAM-NOR (2016) for residential buildings } \\
\text { by Norwegian Green Building Council }\end{array}$ \\
\hline
\end{tabular}




\begin{tabular}{ll}
\hline & Change regulations to cover protection against overheating \\
& - Energy labelling should be less technical than required by TEK10 (2010) and include \\
more general aspects such as daylight & \\
- & Construction (system installation/commissioning/quality control) \\
& - Adjust ventilation rates based on actual needs \\
& - Set out requirements for checking heat exchangers and supply air temperatures \\
\hline UK & Design \\
& - Holistic and coordinated approach to energy \& IEQ in policy making \\
& - Update the Approved Document Part F (HM Government 2010) ${ }^{4}$ and harmonise it with \\
& - international guidelines \\
- & Construction (system installation/commissioning/quality control) \\
& - Strengthen the requirements for system installation \& commissioning \\
& - Improve the arrangements for compliance check to reduce non-compliance
\end{tabular}

${ }^{1}$ The Austrian standard covering requirements on how to design a balanced ventilation for residential buildings. The feedback referred to relaxing certain aspects of the standard, like the use of a 3-level switch. In general, the latest revision (2014) received positive feedback during these interviews.

${ }^{2}$ Since January 2016 a ventilation auditor has to be appointed and the flow rates have to be read and measured. Most interviewees perceived this as a positive change in the new legislation.

${ }^{3} \mathrm{~A}$ recent project proposed a normalised protocol for system installation check: www.promevent.fr

${ }^{4} \mathrm{~A}$ second-tier document to the Building Regulations that sets out the ventilation requirements for buildings in England and Wales.

Technical pushes: In addition to legislative requirements, stakeholders suggested that training and accreditation of installers of ventilation systems would be necessary to improve the quality of installations and avoid problems such as excessive air leakage, unbalanced systems, draughts, noise and poor specific fan power inputs. Furthermore, it was stated that it is important to keep the design as simple as possible, and at the same time flexible for user control. However, a ventilation producer from Belgium stated that manual control is never used because occupants do not have the "natural sensors" to control IAQ. An interviewee in Denmark, on the other hand, pointed out that better IAQ performance in some circumstances may be achieved by refined zonal control and increasing the number of sensors. This shows that finding the right balance between system complexity and IAQ performance objectives seems challenging and that expectations towards a MV system may vary between countries, regions or even projects. It is also important to identify the risk factors and failure modes of a design strategy and specify appropriate mitigation measures throughout the building procurement process.

Financial incentives pulls: The stakeholders suggested that financial incentives in form of government subsidy, grants for specific systems or insurance incentives for system maintenance can be very effective. One stakeholder from Austria estimated that around 50\% of the multifamily housing projects in Tirol, western Austria, utilise balanced ventilation system with heat recovery thanks to additional housing subsidies available for these systems. However, the absence of financial support is seen as positive by one stakeholder in Belgium, who reported that "awareness among general public is too small for a financial stimulus to be enough to convince people to invest in IAQ/ventilation".

Market pulls: The key market requirements identified in the survey were calls for quality labels for ventilation systems, more building products with low emissions, potential market interventions to balance energy effectiveness and cost of installation. Improving occupant awareness of the significance of IAQ and ventilation is also very important. A producer of ventilation systems in Estonia suggested that there must be a level playing field in the market, i.e. uniform competitive conditions. For example, this producer provided additional measures for heat recovery and frost protection in cold climate whereas their competitors do not 
necessarily consider these problems and the potential consequences. Stricter regulatory requirements may lead to improvements in system performance and fairer market competition.

Outreach programmes: Key outreach measures required to facilitate the use of MV were clearer guidance on indoor air quality from the governments, feedback to designers about the actual performance of systems accompanied by education to architects on the need for careful planning of ventilation systems in early design stages. Outreach campaigns to improve the understanding of building administrators and occupants about the benefits of mechanical ventilation should follow. These stakeholders should also receive more information on how to maintain and operate ventilation systems, especially in the context of low-energy buildings.

It should be noted that this survey did not specifically address the users of the installed systems and was more focused on the 'supply' chain. Studies that have investigated the user experience of whole-house balanced mechanical ventilation point out the significance of having a usercentred approach in procurement of these systems (Balvers et al., 2012), adequate user training and Soft Landings (BSRIA, 2009) - a process that includes aftercare and regular system review at the early stages of post-occupancy (Behar, 2016).

\subsubsection{Acceptability of mechanical ventilation}

Seventeen interviewees from stakeholder groups B, C and D responded to the following question regarding acceptability of mechanical ventilation: "In your country, region or building sector, to what extent is mechanical ventilation (with heat recovery) accepted? Please rate from 1 (not accepted) to 10 (fully accepted)". The question was not included in the interview templates for groups A and E. The reported acceptability can be divided in three categories: low - medium (the UK), medium - high (Austria, Belgium and Estonia) and high (Norway). It is interesting to note that in Norway all five stakeholders that were asked this question chose the highest acceptability ranking. There seems to be a trend of higher acceptance level of MV in countries with strong financial incentives for MVHR (Austria) or where it is almost indispensable to install MVHR due to strict energy requirements and climatic conditions (Norway and Estonia). No feedback was received in Denmark for this question.

Regarding the reasons for not using MV already installed in residences (Figure 1), stakeholders ranked noise as the main reason, followed by running costs (energy/electricity), lack of awareness (people not realizing that they have a mechanical system) and operation difficulties. Interviewees were also asked to rank other reasons of their choice. Therein, reported issues included draughts, prejudice against MV, complexity and pathogens fear.

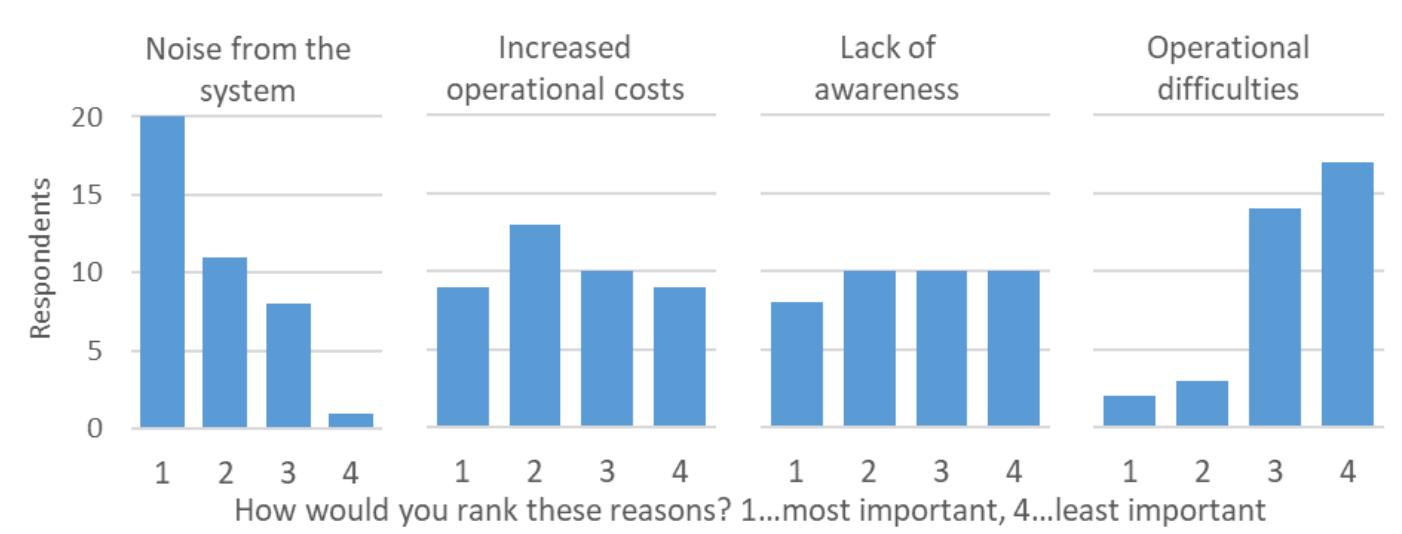

Figure 1. Ranking of key reasons why stakeholders thought MV systems were not used even if already installed. 


\section{CONCLUSIONS}

The review of national building regulations regarding residential ventilation of seven European countries showed that MV systems are dominant in low-energy residential buildings. However, natural ventilation is allowed in the investigated countries if the requirements for ventilation rates and energy performance are fulfilled. The survey indicated that MV is well accepted in countries with financial incentives for MVHR and where climatic conditions and strict energy requirements make heat recovery an almost indispensable feature. There is not a minimum efficiency requirement for heat recovery except in Denmark and Norway. In practice, a counterflow plate heat exchanger is mostly used, followed by a cross-flow heat exchanger. The building codes and standards do not require application of DCV, and it seems to be rare in practice due to higher costs and complexity. In France and Belgium, exhaust-only DCV systems dominate the market as a simple and cost-effective solution compared to MVHR. All seven countries provide a definition of nominal ventilation rate. It is allowed to reduce the airflow below the minimum values in Norway, Austria and Estonia during non-occupancy and in France, Belgium, Estonia and the UK in case of a DCV system.

In total, 44 interviews from seven countries provided a valuable snapshot of current practices in the design and operation of residential ventilation and insights into potential barriers. Several stakeholders pointed out that the capital cost required for MV systems is notably higher than conventional ventilation systems, which is a barrier against wider implementation. Furthermore, MV systems require more space, and duct routing can be challenging. Maintenance and non-compliance with regulatory requirements were also raised as common issues. Finally, noise and the perceived cost of operation were among the key operational problems identified in the survey that may inhibit the use of installed MV systems in dwellings.

To overcome these issues, the main improvement opportunities identified in the survey were: legislative pushes including more flexibility in legislation, codes and building standards, a coordinated approach to energy efficiency and IAQ, and control mechanisms to ensure good implementation and operation. Technical and financial incentives pulls, market pulls and outreach programmes are also required to ensure that mechanical ventilation is effectively used in low-energy dwellings.

\section{DISCLOSURE STATEMENT}

No potential conflict of interest was reported by the authors.

\section{ACKNOWLEDGEMENTS}

The work related to Austria was funded by the Austrian Federal Ministry for Transport, Innovation and Technology. The work related to England and Wales was supported by the EPSRC Project EP/N009703/1 ('TOP'). The work related to Scotland was funded by BRE Trust. The contribution of Cerema is funded by the French Ministries in charge of sustainable development, transport and urban planning. The sole responsibility for the content of this publication lies with the authors. 
The authors would like to thank Targo Kalamees and Ülar Palmiste from Tallinn University of Technology for providing the information about the Estonian regulations, guidelines and performing the stakeholder survey in Estonia.

\section{REFERENCES}

Arrêté 24.03 .82 (1983). Arrêté du 24 mars 1982 relatif à l'aération des logements. JORF 15 novembre 1983.

Arrêté 26.10.2010 (2010). Arrêté relatif aux caractéristiques thermiques et aux exigences de performance énergétique des bâtiments nouveaux et des parties nouvelles de bâtiments, JO 27 octobre 2010.

Balvers, J., Bogers, R., Jongeneel, R., Kamp, I. van, Boerstra, A., \& Dijken, F. van (2012). Mechanical ventilation in recently built Dutch homes: technical shortcomings, possibilities for improvement, perceived indoor environment and health effects. Architectural Science Review, 55 (1), 4-14. https://doi.org/10.1080/00038628.2011.641736

Behar, C.B. (2016). A socio-technical perspective of ventilation practices in UK social housing with whole house ventilation systems; design, everyday life and change. PhD Dissertation, University College London (UCL), London, UK.

Boerstra, A. (2012). Residential ventilation system performance: outcomes of a field study in the Netherlands. In: AIVC-TightVent Conference Proceedings, Copenhagen, Denmark.

BR15 (2017). The Danish Building Regulations. Ministry of Transport, Construction and Housing.

BR18 (2019). The Danish Building Regulations. Ministry of Transport, Construction and Housing.

BRE (2012). The Government's Standard Assessment Procedure for Energy Rating of Dwellings, BRE, Watford, UK.

BREEAM-NOR (2016). BREEAM-NOR New Construction 2016. Technical manual. Norwegian Green Building Council.

BSRIA (2009). The Soft Landings Framework for better briefing, design, handover and building performance inuse. BSRIA BG 4/2009. BSRIA, Bracknell, UK.

Bøhlerengen, T. (2017). Byggforskserien. SINTEF Byggforsk. Norwegian Building Research Series guidelines. ISSN 2387-6328. Available at: https://www.byggforsk.no/byggforskserien

Caillou, S. \& Van den Bossche, P (2016). Praktische gids voor de basis- ventilatiesystemen voor woon- gebouwen. Technische voorlichtingen Nr. 258. Wetenschappelijk en Technisch Centrum voor het Bouwbedrijf (WTCB). (in Dutch)

Caillou, S., Van den Bossche, P., Dinne, K., \& Vandaele, L. (2012). Performances of ventilation systems : on site measurements related to energy efficiency, comfort and health. In: AIVC-TightVent Conference Proceedings. Copenhagen, Denmark.

CCFAT (2015). VMC Simple Flux hygroréglable - Règles de calculs pour l'instruction d'une demande d'avis techniques - GS14.5 - Equipements / Ventilation et systèmes par vecteur air.

CEN/TR 14788:2006. Ventilation for buildings. Design and dimensioning of residential ventilation systems. Technical Report, European Committee for Standardization.

Colcough, S., Kinnane, O., Hewitt, N., \& Griffiths, P. (2018). Investigation of nZEB social housing built to the Passive House standard. Energy and Buildings, 179, 344-359. https://doi.org/10.1016/j.enbuild.2018.06.069

Commission Delegated Regulation (EU) No 1254/2014 of 11 July 2014 supplementing Directive 2010/30/EU of the European Parliament and of the Council with regard to energy labelling of residential ventilation units. Journal of the European Union.

Dimitroulopoulou C. (2012). Ventilation in European dwellings: A review. Building and Environment, 47, 109125. https://doi.org/10.1016/j.buildenv.2011.07.016

Directive 2002/91/EC. Directive 2002/91/EC of the European Parliament and of the Council of 16 December 2002 on the energy performance of buildings.

Directive 2010/31/EU. Directive 2010/31/EU of the European Parliament and of the Council of 19 May 2010 on the energy performance of buildings.

Directive 2012/27/EU. Directive 2012/27/EU of the European Parliament and of the Council of 25 October 2012 on energy efficiency, amending Directives 2009/125/EC and 2010/30/EU and repealing Directives 2004/8/EC and 2006/32/EC.

DS 447:2013. Ventilation in buildings - mechanical, natural and hybrid ventilation system. Danish Standards.

DTU 68.32. (2017). Afnor. NF DTU 68.3 Avril 2017. Travaux de bâtiment - Installations de ventilation mécanique.

EN 12237:2003. Ventilation for buildings - Ductwork - Strength and leakage of circular sheet metal ducts for duct testing. European Committee for Standardization. 
EN 15665:2009. Ventilation for buildings. Determining performance criteria for residential ventilation systems. European Committee for Standardization.

Energiebesluit 19/11/2010 (2010). Vlaams Energiebesluit van 19 november 2010, bijlage V en IX. Vlaams Regering.

Estonian legal acts 11.12.2018 no. 63 (2018). Minimum requirements for energy performance of buildings. Minister of Economic Affairs and Infrastructure. (in Estonian: Ettevõtlus- ja infotehnoloogiaministri määrus nr 63 (11.12.2018). Hoone energiatõhususe miinimumnõuded)

EVS-EN 16798-1:2019. Energy performance of buildings - Ventilation for buildings - Part 1: Indoor environmental input parameters for design and assessment of energy performance of buildings addressing indoor air quality, thermal environment, lighting and acoustics - Module M1-6. Estonian Centre for Standardisation.

EVS-EN 16798-1:2019/NA:2019. Energy performance of buildings - Ventilation for buildings - Part 1: Indoor environmental input parameters for design and assessment of energy performance of buildings addressing indoor air quality, thermal environment, lighting and acoustics - Module M1-6. Estonian National Annex. Estonian Centre for Standardisation.

Guyot, G., Melois, A., Bernard, A.-M., Coeudevez, C.-S., Déoux, S., Berlin, S., Parent, E., Huet, A., Berthault, S., Jobert, R., \& Labaume, D. (2017). Ventilation performance and indoor air pollutants diagnosis in 21 French low energy homes. International Journal of Ventilation, 17(3), 187-195. https://doi.org/10.1080/14733315.2017.1377393

Guyot, G., Walker, I.S., \& Sherman, M.H. (2018). Performance based approaches in standards and regulations for smart ventilation in residential buildings: a summary review. International Journal of Ventilation, 0, 1-17. https://doi.org/10.1080/14733315.2018.1435025

HM Government (2010). The Building Regulations 2010. Ventilation. Approved document F: F1 Means of ventilation (2010 edition incorporating 2010 and 2013 amendments).

HM Government. (2013). The Building Regulations 2010. Approved Document L1A: Conservation of fuel and power in new dwellings (2013 edition with 2016 amendments). London: NBS.

IEA EBC Annex 68. IEA EBC Annex 68 "Indoor Air Quality Design and Control in Low Energy Residential Buildings. Energy in Buildings and Communities Program. http://www.iea-ebc-annex68.org/ (accessed 15.01.2019)

Jobert, R., \& Guyot, G. (2013). Detailed analysis of regulatory compliance controls of 1287 dwellings ventilation systems. In: Proceedings of the 34th AIVC-3rd TightVent-2nd Cool Roofs'-1st Venticool Conference, Athens, Greece.

Mahdavi, A., \& Doppelbauer, E.-M. (2010). A performance comparison of passive and low-energy buildings. Energy and Buildings, 42, 1314-1319. https://doi.org/10.1016/j.enbuild.2010.02.025

McGill, G., Qin, M., \& Oyedele, L. (2014). A case study investigation of indoor air quality in UK Passivhaus dwellings. Energy Procedia, 62, 190-199. https://doi.org/10.1016/j.egypro.2014.12.380

NBN D 50-001 (1991). Ventilation systems for housings. Belgian Institute for Normalization (BIN) Brussel.

OIB-Richtlinie 3 (2019). Hygiene, Gesundheit und Umweltschutz. Richtlinien des Österrreichischen Instituts für Bautechnik.

OIB-Richtlinie 6 (2019). Energieeinsparung und Wärmeschutz. Richtlinien des Österrreichischen Instituts für Bautechnik

ÖNORM H 6038 (2014). Ventilation and air conditioning plants - Controlled residential ventilation including heat recovery - Planning, installation, operation and maintenance. Austrian Standards Institute. Wien.

Ploß, M. (2016). Leistbares Wohnen. Max50 - Z. Energieinstitut Vorarlb. 22-23.

Rojas, G., Pfluger, R., \& Feist, W. (2015). Cascade ventilation - Air exchange efficiency in living rooms without separate supply air. Energy and Buildings, 100, 27-33. doi:10.1016/j.enbuild.2015.02.014

Rojas, G., Wagner, W., Suschek-Berger, J., Pfluger, R., \& Feist, W. (2016). Applying the passive house concept to a social housing project in Austria - evaluation of the indoor environment based on long-term measurements and user surveys. Advances in Building Energy Research, 10(1), 125-148. https://doi.org/10.1080/17512549.2015.1040072

Sharpe, T., McGill, G., Rajat, G., Gregg, M., \& Mawditt, I. (2016). Characteristics and performance of MVHR systems. A meta study of MVHR systems used in the Innovate UK Building Performance Evaluation Programme. Report.

TEK10 (2010). Norwegian regulations on technical requirements for construction works. Norwegian Building Authority.

TEK17 (2017). Norwegian regulations on technical requirements for construction works. Norwegian Building Authority. https://dibk.no/byggereglene/byggteknisk-forskrift-tek17/ (accessed 28.1.2019)

The Scottish Government (2015). Scottish building regulations: Technical Handbook - Domestic. 
Wallner, P., Munoz, U., Tappler, P., Wanka, A., Kundi, M., Shelton, J.F., \& Hutter, H.P. (2015). Indoor environmental quality in mechanically ventilated, energy-efficient buildings vs. Conventional buildings. International Journal of Environmental Research and Public Health, 12(11), 14132-14147. https://doi.org/10.3390/ijerph121114132

Wang, Z., Xue, Q., Ji, Y., \& Yu, Z. (2018). Indoor environment quality in a low-energy residential building in winter in Harbin. Building and Environment, 135, 194-201. https://doi.org/10.1016/j.buildenv.2018.03.012

Working draft for requirements for building indoor environmental quality and airing (2015). (in Estonian: Hoone sisekliima ja õhustuse nõuded). To be implemented 2019.

Van den Bossche, P., Sabrina Prieus, S. \& Cootjans, P. (2007). Ventilatiegids, stappenplan voor comfortabel en energiezuinig ventileren. Wetenschappelijk en Technisch Centrum voor het Bouwbedrijf (WTCB) and Hogeschool voor Wetenschap en Kunst - De Neyer Instituut (DNI). (in Dutch) https://www.cstc.be/homepage/download.cfm?lang=nl\&dtype=publ\&doc=Ventilatiegids\%20woningen.p df

Vorre, M.H., Wagner, M.H., Maagaard, S.E., Noyé, P., Lyng, N.L. \& Mortensen, L.H. (2017). Branchevejledning for indeklimaberegninger. National Danish Building Research Institut. (in English: (Guideline for indoor climate calculations). 